\title{
Relationship between Organisational Commitment and Demographic Variables: Evidence from a Commercial Bank in Ghana
}

\author{
Emmanuel Affum-Osei ${ }^{*}$, Ebenezer Acquaah², Phinihas Acheampong 3 \\ ${ }^{1}$ School of Management and Economics, University of Electronic Science and Technology of China, Chengdu, China \\ ${ }^{2}$ Center for Distance Education, University of Education, Winneba, Ghana \\ ${ }^{3}$ Faculty of Education, Beijing Normal University, Beijing, China \\ Email: ‘affumnanaosei@yahoo.com
}

Received 23 November 2015; accepted 14 December 2015; published 17 December 2015

Copyright (C) 2015 by authors and Scientific Research Publishing Inc.

This work is licensed under the Creative Commons Attribution International License (CC BY).

http://creativecommons.org/licenses/by/4.0/

(c) (i) Open Access

\begin{abstract}
Organisational commitment is very important for employees of every organisation. The construct has been much researched because of its impact on performance. The objective of the current study was to find out the relationship between organizational commitment and demographic variables (gender, age, qualification, experience and marital status) in Ghana. A descriptive correlation survey was employed in the study. Questionnaire was the main instrument used to gather the data for the current study. A total of 206 employees were randomly selected from 10 branches of a commercial bank in Ghana. The results showed that majority of the employees were moderately and highly committed with male workers recording the highest level of commitment compared to their female counterparts. The study further indicated that, there is evidence of significant relationship between organizational commitment and demographic variables (gender, age, qualification, experience and marital status). In conclusion, some of the organisational policies should be geared towards the improvement of employees' commitment in order to enhance their performance.
\end{abstract}

Keywords

Organisational Commitment, Demographic Variables, Commercial Bank, Ghana

\section{Introduction}

Organisational commitment has been regarded as one of the important constructs that aid employees’ perfor-

"Corresponding author.

How to cite this paper: Affum-Osei, E., Acquaah, E. and Acheampong, P. (2015) Relationship between Organisational Commitment and Demographic Variables: Evidence from a Commercial Bank in Ghana. American Journal of Industrial and Business Management, 5, 769-778. http://dx.doi.org/10.4236/ajibm.2015.512074 
mance. The success of an organization does not only be based on motivation, high pay or training but also how employees are committed to the organization. Commitment at workplace can take various forms and arguably has the potential to influence organizational effectiveness and employees' well-being [1]. Organisational commitment is a bond or linking of the individual to the organization [2] and it makes an individual to be identified with a particular organization [3]. This psychological link between the employee and his or her organization makes it less likely that the employee will voluntarily leave the organization [4]. The role of organizational commitment plays in healthy organizational climate and high productivity cannot be overemphasized. Recently, many employees in organisations are concern about companies' policies of continuous job redesigning and downsizing [5]. Therefore, the need for researchers is to investigate the role of commitment playing in maintaining good working environment for employees to ensure high performance. Research by [6] suggested four categories of variables that affect organizational commitment which included personal characteristics, job characteristics, work characteristics and structural characteristics. However, many researchers have linked organizational commitment to several variables such as job satisfaction [7] [8], emotional intelligence [9] [10], occupational stress [11] [12], achievement motivation [8], job performance [13], organizational citizenship behavior [14] and turnover intentions [15]-[17]. Indeed, some studies have also found a relationship between organizational commitment and some demographic characteristics [18]-[20]. But most of these researches have focused on the developed world and few of such studies have been conducted in sub-Saharan Africa [21]. This has necessitated the current study in Ghanaian context to provide empirical evidence in order to contribute to the commitment-demographic relationship literature. The current study will identify the level of organizational commitment of bank employees and also find out whether there is a significant evidence of relationship between orgnisational commitment and demographic variables including gender, age, experience, qualification and marital status.

\section{Review of Related Literature}

\subsection{Organisational Commitment}

Commitment comes into being when a person by making a side bet, links extraneous interests with a consistent link of activity [22]. In his study, [23] defines commitment as one's inclination to act in a given way toward a particular commitment target. Commitment is an obliging force which requires that the person honour the commitment even in the face of fluctuating attitudes and whims [24]. According to [25] commitment is a stabilizing force, that force acts to maintain behavioural direction when expectancy/equity conditions are not met and do not function. Organisational commitment has also been defined as a psychological attachment of a person to the organization. Commitment is the relative strength of an individual's identification with and involvement in a particular organization [3]. Organisational commitment is a bond or linking of the individual to the organization [2]. Organisational commitment can be defined generally as a psychological link between the employee and his or her organization that makes it less likely that the employee will voluntarily leave the organization [4]. Organisational commitment over the years has been defined and measured in many ways [6] [26]. The lack of consensus in the definition of oganisational commitment contributed greatly to its treatment as a multidimensional construct [4]. Authors such as [22] viewed commitment as the common element linking different forms of commitment within multidimensional models. In their various studies on commitment [1] [23]-[25], believe that commitment has a core essence that distinguishes it from other constructs. All the definitions of commitment in general made reference to the fact that commitment a) stabilizing or obliging force, that b) gives directions to behaviour (restricts, freedom, binds the person to a course of action) [1].

\subsection{Organisational Commitment and Demographic Characteristics}

Over the years, many researches have associated demographic factors with organisational commitment [2] [10] [27]-[30]. Previous works that have shown the relationship between organizational commitment and gender, age, qualification, experience and marital status have been reviewed.

\subsubsection{Gender and Organisational Commitment}

There is the need to include gender as a key variable in future research [31] because the interaction of values with gender was also found to be a significant predictor of commitment [19]. A study by [2] suggested that, al- 
though reported a weak relationship between gender and organisational commitment but suggested that, gender may affect employees' attitude towards the organisation. In a study to finding out the level of commitment of family and non-family member of family businesses, [30] indicated that female employees were highly committed compared to their male counterparts. In a related study, [32] also found that, males were found to be more committed to their respective organization compared to females and the relationship between authority and the related attitude of work commitment is positive for men but negative for women [33] but this low level of commitment among female employees may be attributed to high level of discrimination at work places [34]. In related study on demographic and psychological factors predicting organisational commitment among industrial workers [10], showed that gender was not significant predictor of organizational commitment. A work by [35] also found no difference in male and females overall commitment. Based on this theoretical background, we propose our first hypothesis in alternative form that:

H1: There will be an evidence of significant relationship between gender and organisational commitment.

\subsubsection{Age and Organisational Commitment}

Demographic characteristic age has been found to be significant related with organizational commitment [10] [27] [36] [37]. In a study to investigate the nature of demographic factors (age and job tenure) and job satisfaction facets with organizational commitment, [29] found out that the demographic factors (age and job tenure) predicted organizational commitment (see also 10). A study by [35] found that, affective commitment in 21 - 28 years old group were higher than those 29 - 39 years old and 40 years and upper. In a similar study to find out the significant influence on organizational commitment in Saudi Arabia public sector organizations with demographic variables and job and work related variables [38] found out that age is positively related to organizational commitment and older employees tend to be more committed compared to younger employees. In a study to find out the relationship between a specific demographic variables and organisationsl commitment in a Nigeria sample, [21] find a positive relationship between age and organizational commitment. He argues that commitment increase with age. However, [10] found no significant correlation between age and organizational commitment. We therefore, offer the following proposition that:

H2: There will be an evidence of significant relationship between age and organisational commitment.

\subsubsection{Qualification and Organisational Commitment}

Educational level has also been found to be related to organizational commitment [10] [27] [38] [39]. According to [2], there is a strong relationship between educational level and orgnaisational commitment. It is likely that workers with high educational qualifications occupy higher ranks and therefore have more responsibilities which invariably require more commitment to the organization [10] and that educational level may lead to high level of commitment [21]. On the contrary, [38] and [40] found that educational level is negatively related with organizational commitment and that more educated people may have high expectations which the organization be unable to meet them. According to [40] highly educated individuals may have less commitment since they may have other opportunities of employment. Again, [30] found that, employees who were having certificates from first degrees and below showed high committed compared to those with higher qualifications. Therefore, we propose that:

H3: There will be an evidence of a significant relationship between qualification and organisational commitment.

\subsubsection{Experience and Organisational Commitment}

Experience or long service in a particular sector may also lead to high level of commitment. For instance, job tenure is a significant predictor of organizational commitment [10] [29] [40] Research highlights the importance of work experiences that commitment that the organization is supportive of its employees treats them fairly and enhances their sense of personal importance and competence by appearing to value their contributions to the organization [41] (see also [42]).

According to [21], years worked (i.e. tenure) have an overwhelming influence on commitment. In a study to the extent, to which faculty members are committed to their University, [40] showed that length of service is highly significant and positively associated with organizational commitment. He argues that, the longer an employee stays in the organization and the older they become the feelings of responsibilities for outcomes relevant to him also increases. In a related study, [35] found that, employees who had 1 - 4 years job tenure obtained high mean scores on total scores of organizational commitment in comparison with those who had 9 years and upper 
job tenure. Consequently, we offer the following proposition that:

H4: There will be an evidence of a significant relationship between experience and Organizational Commitment.

\subsubsection{Marital Status and Organisational Commitment}

Many researches have shown that employees who are married show much more commitment to their organisations compared to single employees [36]. In a study on demographic and psychological factors predicting organizational commitment, [10] found that marital status of employees significantly predicted organizational commitment. He suggested that individual workers who are married are much committed than individuals who are single. We propose the following alternative hypothesis that:

H5: There will be an evidence of a significant relationship between Marital Status and Organisational Commitment.

\section{Methodology}

In the current research, quantitative research method was used as data were presented in the form of numbers [43]. Quantitative research emphasizes the measurement and analysis of causal relationships between variables [44] and aims at drawing representative sample for the population [45]. The population for the study comprised employees of a commercial bank in Ghana. The banking sector is very lucrative in Ghana and many young graduates aim at working for the banks. It is interesting to identify whether the employees working in the banks are committed or because of the lucrative nature of the sector that attracts many young people to the banking sector. Letters were sent to the various banks to inform them about the study as well as seeking consent from the participants to voluntarily take part in the study. The purpose of the study was well explained to the participants and permission was granted by the bank authority before the questionnaires were distributed to the sample. It is almost impossible to study all the workers of the bank. Therefore, the researchers sampled twenty (20) branches of the commercial banks for the study. Ten (10) branches were selected from Greater Accra Region and ten (10) from the Central Region of Ghana. Stratified random sampling which is a variant of random sampling, which allows subgroups to be studied in greater detail [45] was used for this study. Based on this background, two regions were sample from the ten regions in Ghana. The branches of commercial banks from the regions were group into strata. Ten branches were randomly selected from each subgroup (branches). In all, twenty branches were selected and twenty five (25) questionnaires were sent to each branch making a total five hundred employees to answer the questionnaire. However, out of the five hundred questionnaires sent to the banks, 104 were received from the strata in Greater Accra Region and 102 from the branches in the Central Region. This means that a total of two hundred and six (206) sample representing $41.2 \%$ were retrieved and used for the study. The response rate was due to the busy schedule of the bank employees. Someone of the respondents failed to return the questionnaires citing inadequate time to complete the questionnaires. In measuring organisational commitment, the commitment scale developed by [4], also [1] was used in the study. The internal consistency of the original scale has been estimated using coefficient alpha. The median reliabilities, across both versions of the ACS, CCS, and NCS are $0.85,0.79$, and 0.73 respectively, and with very few exceptions, all reliability estimates exceed 0.70 [4]. The Cronbach's Alpha for this study ranges from 0.91 to 0.93 with a total alpha of 0.96 for 24 items. Nevertheless, research using the ACS, CCS and NCS has consistently yielded non-zero correlation between the scales [7]. This is the same for the current study as all the subscales of the OCS showed high internal consistency. The Statistical Package for Social Sciences (SPSS 22.0) was used to conduct the analysis of the collected data. The completed questionnaires were serially numbered for easy identification and were finally scored. Items on the five point-likert scale were scored 1, 2, 3, 4 and 5 for items with the response strongly disagree, disagree, neither agree nor disagree, agree and strongly agree respectively. Cross-tabulation was run to generate the counts of the level of stress of the participants in percentages. Chi-square test of independence was used to test the hypotheses of the study in order to determine whether there is significant association between the variables under study.

\section{Results and Discussion}

\subsection{Demographic Characteristics of the Respondents}

In research of such nature the background statistical information of the respondents is very important. Table 1 provide the background statistical information of the respondents. 
Table 1. Demographic distribution of respondents.

\begin{tabular}{|c|c|c|c|}
\hline Items & & Frequency (n) & Percentage (\%) \\
\hline \multirow[t]{2}{*}{ Gender } & Male & 92 & 44.7 \\
\hline & Female & 114 & 55.3 \\
\hline Total & & 206 & 100 \\
\hline \multirow[t]{3}{*}{ Age } & $20-30$ & 46 & 22.3 \\
\hline & $31-40$ & 91 & 44.2 \\
\hline & 41 and above & 69 & 33.5 \\
\hline Total & & 206 & 100 \\
\hline \multirow[t]{3}{*}{ Qualification } & Bachelor & 132 & 64.1 \\
\hline & Master & 68 & 33 \\
\hline & Above Master’s & 6 & 2.9 \\
\hline Total & & 206 & 100 \\
\hline \multirow[t]{3}{*}{ Experience } & $1-3$ yrs & 50 & 24.3 \\
\hline & $4-7$ yrs & 84 & 40.8 \\
\hline & 8 yrs and above & 72 & 35 \\
\hline Total & & 206 & 100 \\
\hline \multirow[t]{3}{*}{ Marital Status } & Single & 125 & 60.7 \\
\hline & Married & 69 & 33.5 \\
\hline & Divorced & 12 & 5.8 \\
\hline Total & & 206 & 100 \\
\hline
\end{tabular}

Source: field data.

Table 1 represents the demographic characteristics of the respondents. The results show that out of a sample of 206, 92 (44.7\%) were males and 114 (55.3\%) were females. This result shows that majority of the employees were females. In terms of age, out of the three categories given, 46 (22.3\%) fall within the 20 - 30 years category, 91 (44.2\%) were within 31 - 40 years category and 69 representing 33.5\% falls within 41 and above age range. Majority of the employers were within the ages of 30 - 40. Approximately $64.1 \%$ of the respondents hold bachelor's degrees, 33\% hold postgraduate degree and $2.9 \%$ holds research degrees. In reference to experience, $24.3 \%$ of the respondents had 1 - 3 years experience on the banking job $40.8 \%$ had 4 - 7 years' experience and a total of 72 representing $35 \%$ had 8 years and above experience. With regard to marital status of the respondents, three categories namely married, single and divorced, $60.7 \%$, were single, $33.5 \%$ were married and $5.8 \%$ were divorced.

\subsection{The Level of Organisational Commitment on Demographic Variables}

One of the aims of the study is to identify the level of organizational commitment of the participants of the study. Table 2 provides the level of commitment of the demographic characteristics (gender, age, qualification experience and marital status).

There were 206 participants in the study, out of these 92 representing $44.7 \%$ were males of which 25 (27.2\%) recorded low commitment, 35 (38\%) were moderately committed and 32 (34.8\%) were highly committed. There were 114 (55.3\%) females out of these, 28 (24.6\%) had low commitment, 55 (48.2\%) had moderate commitment and 31 (27.2\%) had high commitment level. The current results shows that, majority of the employees were moderately committed 90 (43.7\%). 
Table 2. The level of organisational commitment of bank employees on demographic variables.

\begin{tabular}{|c|c|c|c|c|c|}
\hline & Variables & Low & Moderate & High & Total \\
\hline & N (\%) & N (\%) & N (\%) & N (\%) & N (\%) \\
\hline \multirow[t]{2}{*}{ Gender: } & Male & 25 (27.2) & $35(38)$ & 32 (34.8) & $92(100)$ \\
\hline & Female & 28 (24.6) & 55 (48.2) & 31 (27.2) & $114(100)$ \\
\hline Total & & $53(25.7)$ & 90 (43.7) & 63 (30.6) & $206(100)$ \\
\hline \multirow[t]{3}{*}{ Age: } & $20-30$ & 10 (21.8) & 18 (39.1) & 18 (39.1) & $46(100)$ \\
\hline & $31-40$ & 29 (31.9) & 44 (48.4) & 18 (19.7) & $91(100)$ \\
\hline & 41 and above & 14 (20.3) & 27 (39.1) & $28(40.6)$ & $69(100)$ \\
\hline Total & & 53 (25.7) & 89 (43.2) & 64 (31.1) & 206 (100) \\
\hline \multirow[t]{3}{*}{ Qualification: } & Bachelor & 27 (20.4) & $53(40.2)$ & $52(39.4)$ & $132(100)$ \\
\hline & Master & 27 (39.7) & 33 (48.5) & 8 (11.8) & $68(100)$ \\
\hline & Above Master & $1(16.7)$ & $2(33.3)$ & $3(50.0)$ & $6(100)$ \\
\hline Total & & 55 (26.7) & 88 (42.7) & $63(30.6)$ & $206(100)$ \\
\hline \multirow[t]{3}{*}{ Experience: } & $1-3 \mathrm{yrs}$ & 15 (30.0) & $18(36.0)$ & 17 (34.0) & $50(100)$ \\
\hline & $4-7 y r s$ & 20 (23.8) & 40 (47.6) & 24 (28.6) & $84(100)$ \\
\hline & 8yrs and above & 20 (27.8) & $31(43.0)$ & $21(29.2)$ & $72(100)$ \\
\hline Total & & 55 (26.7) & 89 (43.2) & $62(30.1)$ & $206(100)$ \\
\hline \multirow[t]{3}{*}{ Marital Status: } & Single & 30 (24.0) & $54(43.0)$ & $41(33.0)$ & $125(100)$ \\
\hline & Married & 21(30.4) & $29(42.1)$ & 19 (27.5) & $69(100)$ \\
\hline & Divorce & $3(25.0)$ & $6(50.0)$ & $3(25.0)$ & $12(100)$ \\
\hline Total & & $54(26.2)$ & 89 (43.2) & 63 (30.6) & $206(100)$ \\
\hline
\end{tabular}

Source: field data.

There were 46 (22.3\%) of employees within the age of 20 - 30 years of which 10 (21.8\%) had low commitment 18 (39.1\%) had moderate commitment and 18 (39.1\%) had high commitment level. 31 - 40 year category were 91 (44.2\%) out of which 29 (31.9\%) had low commitment level, 44 (48.4\%) were moderately committed and 18 (19.7\%) were highly committed. There were 69 (33.5\%) employees who fall within the 41 years and above age range, out of this total 14 (20.3\%) had low commitment level, 27 (39.1\%) had moderate commitment and 28 (40.6\%) were highly committed.

Data on qualification show that, out of a total of 132 (64.1\%) bachelor's degree employees 27 (20.4\%) had low commitment, 53 (40.2\%) were moderately committed and 52 (39.4\%) were highly committed. 68 (33\%) were master's degree holders out of these, 27 (39.7\%) had low commitment, 33 (48.5\%) had moderate commitment and 8 (11.8\%) were highly committed. Employees who holds degrees above master's level were 6 (2.9\%), out of this total, 1 (16.7\%) had low commitment 2 (33.3\%) were moderately committed and 3 (50\%) were highly committed.

There were 50 (24.3) employees with 1 - 3 years experience out of the total, 15 (30\%) had low commitment, 18 (36\%) were moderately committed and 17 (34\%) had high commitment levels. Employees who had 4 - 7 years job experience were 84 (40.8\%) of which 20 (23.8\%) had low commitment, 40 (47.6\%) were moderately stressed and 24 (28.6\%) were highly committed. 72 employees had 8 years and above of experience out of this, 20 (27.8\%) had low commitment, 31 (43\%) were moderately commitment and 21 (29.2\%) were highly committed.

Data collected on marital status shows that, single employees were 125 (60.7\%) of which 30 (24\%) had low commitment level 54 (43\%) were moderately committed and 41 (33\%) had high commitment. Married em- 
ployees were 69 (33.5\%) out of which 21 (30.4\%) had low commitment 29 (42.1\%) recorded moderate commitment and 19 (27.5\%) were highly commitment. 12 employees were divorced employees out of which 3 (25\%) had low commitment, 6 (50\%) were moderately commitment and 3 (25\%) were moderately committed.

\subsection{Chi-Square Results of Organisational Commitment}

The level of stress on demographic variables have been ascertain in Table 2. In order to find out whether there is a significant relationship between demographic characteristics and organisational commitment, the Chi-square test was applied.

Table 3 shows the results of Chi-Square. It shows that there is an evidence of relationship between demographic variables (gender, age, qualification, experience and marital status) and organisational commitment. The results further indicate that experience has the greatest evidence of association with organizational commitment (Chi-Square $=381.136, p<0.01)$ and gender having the lowest evidence of relationship with organisationl commitment (Chi-Square $=60.601)$. Therefore, it may be concluded that, there is very strong evidence of a relationship between demographic characteristic and organisational commitment.

\section{Discussion}

The results on the level of commitment showed that, majority of the employees were moderately committed. Male employees were found to be highly committed compared to their female counterparts. The finding is consistent with the findings of [32], who reported that, males were found to be more committed to their respective organization compared to females in service sector in Ghana. The results further show that gender has a significant relationship with organisational commitment. Other researchers have found that gender was no significant predictor of overall commitment [10] [35]. The findings may be due to the position of males in the hierarchy of the organisations. As is suggested by [8], that males have higher organisational commitment than female but this may be due to their position in the hierarchy. The study also revealed that older employees were more committed to the organization compared to the younger employees. This research confirmed the findings of [38] and [29] who found out that age is positively related to organizational commitment and older employees tend to be more committed compared to younger employees (10). This result may due to the fact that younger employees have more job opportunities compared to older employees on the other hand, older employees perceived to have invested much in the organization and their turnover intension reduces as the years go by. As [21], argues "commitment increase with age and there is a positive relationship between age and organisational commitment”. The results further showed that high qualification employees had high level of commitment. Employees who hold above master's degree showed high of commitment. The result was consistent with the finding of [21] who suggests that highly educational qualification may lead to high commitment level. This result may be as a result that, in Ghanaian society people with higher qualification occupy higher positions in the workplaces and are entrusted with high level of commitment. As [10] argues "It is likely that workers with high educational qualifications occupy higher ranks and therefore have more responsibilities which invariably require more commitment to the organization". However, [40] also argued that, highly educated individuals may have less commitment since they may have other opportunities of employment. Again, [30] found that, employees who had first degrees and below showed high committed compared to those with higher qualifications. This finding contradicts the current because the responded were employees of family businesses. The employees with less level of

Table 3. Chi-square results of commitment and demographic variables.

\begin{tabular}{ccc}
\hline Variables & Chi-square values & Significance \\
\hline Gender & 60.601 & 0.000 \\
Age & 358.986 & 0.000 \\
Qualification & 364.071 & 0.000 \\
Experience & 381.136 & 0.000 \\
Marital status & 239.516 & 0.000 \\
\hline
\end{tabular}

\footnotetext{
${ }^{* *} p<0.01$.
} 
experience tend to report the highest level of commitment. Employees who had 1 - 3 years job experience tend to report high level of commitment. This finding suggest that employees who have low level of experience have less job opportunities because high level of experience is required for graduates to be employed in the banking sector in Ghana and are therefore committed to stay. According to [41], one is committed to stay with an organisation because they need the financial security. The finding of the current study is in support of [35] whose results show that, employees who had 1 - 4 years job tenure obtained high mean scores on total scores of organizational commitment in comparison with those who had 9 years and upper job tenure. The finding is in contrast with the result obtained by [40] who argues that, the longer an employee stays with the organization and the older they become the feelings of responsibilities for outcomes relevant to him also increases. [10] also argued that, workers who had higher job tenure had more commitment than newly employed and that workers who expected to stay longer in the department were more committed [8]. These contradictions may be attributed to the type of job settings and the geographical location of the researches. The results further suggested that single employees were more committed to their job compared with married and divorced employees. This may be due to the fact that, married individuals may face the family-work balance and their commitment levels may be divided. They may tend to be committed to their families. However, single employees may not have such marriage or family commitments and tend to show overall commitment to the organisation. [10] suggested that individual workers who are married are much committed than individuals who are single. This accession contradicts with the current research findings. The Chi-Square was applied and the results showed a statistically significant relationship between the demographic variables (Gender, age, qualification, experience and marital status) and organisational commitment. The researchers therefore conclude that, there is a strong evidence of association between demographic variables and organisational commitment.

\section{Conclusion}

The study has provided information on demographic variables since individuals differ in terms of their commitment levels to organisations. Therefore, employers should take note and take the necessary measures to enhance commitment based on individual differences. Some of the organisational policies should be geared towards the improvement of employees' commitment in order to enhance performance. Despite the positive impact of this study, the study has some limitations which should be considered when the results are being interpreted. The study was a descriptive correlation and this implies that causal relationship cannot be made. Again, the study used relatively small sample $(\mathrm{N}=206)$ and therefore, the findings cannot be generalized to all other institutions.

\section{References}

[1] Meyer, J.P. and Herscovitch, L. (2001) Commitment in the Workplace: Toward a General Model. Human Resource Management Review, 11, 299-326. http://dx.doi.org/10.1016/S1053-4822(00)00053-X

[2] Mathieu, J.E. and Zajac, D.M. (1990) A Review and Meta-Analysis of the Antecedent, Correlates, and Consequences of Oganisational Commitment. Psychological Bulletin, 108, 171-194. http://dx.doi.org/10.1037/0033-2909.108.2.171

[3] Allen, N.J. and Meyer, J.P. (1996) Affective, Continuance and Normative Commitment to the Organisation, an Examination of Construct Validity. Journal of Vocational Behaviour, 49, 252-276. http://dx.doi.org/10.1006/jvbe.1996.0043

[4] Feldman, C.D. (1995) The Impact of Downsizing on Organizational Career Development Activities and Employee Career Development Opportunities. Human Resource Management Review, 5, 189-221. http://dx.doi.org/10.1016/1053-4822(95)90002-0

[5] Mowday, R.T., Steers, R.M. and Porter, L.W. (1979) The Measurement of Organizational Commitment. Journal of Vocational Behaviour, 14, 224-247. http://dx.doi.org/10.1016/0001-8791(79)90072-1

[6] Mowday, R.T., Porter, L.W. and Steers, R.M. (1982) Employee-Organisation Linkages: The Psychology of Commitment, Absenteeism and Turnover. Academic Press, New York.

[7] Meyer, J.P., Stanley, D.J., Herscovitch, L. and Topolnytsky, L. (2002) Affective, Continuance, and Normative Commitment to the Organization: Meta-Analysis of Antecedents, Correlates, and Consequences. Journal of Vocational Behaviour, 61, 20-52. http://dx.doi.org/10.1006/jvbe.2001.1842

[8] Savery, K.L. and Syme, D.P. (1996) Organisational Commitment and Hospital Pharmacists. Journal of Management Development, 15, 14-22. http://dx.doi.org/10.1108/02621719610107773

[9] Aghdasi, S., Kiamanesh, R.A. and Ebrahim, N.A. (2011) Emotional Intelligence and Organisational Commitment: 
Testing the Mediatory Role Occupational Stress and Job Satisfaction. Social and Behavioural Sciences, 29, 1965-1976.

[10] Salami, S.O. (2008) Demographic \& Psychological Factors Predicting Organisational Commitment among Industrial Workers. Anthropologist, 10, 31-38.

[11] Siu, O. (2003) Job Stress and Job Performance among Employees in Hong Kong: The Role of Chinese Work Values and Organizational Commitment. International Journal of Psychology, 38, 337-347. http://dx.doi.org/10.1080/00207590344000024

[12] Jackson, L. and Rothmann, S. (2006) Occupational Stress, Organizational Commitment, and Ill-Health of Educators in the North West Province. South African Journal of Education, 26, 75-95.

[13] Jamal, M. (2011) Job Stress, Job Performance, and Organisational Commitment in a Multinational Company. An Empirical Study in Two Countries. International Journal of Business and Social Sciences, 2, 20-29.

[14] Mamman, A., Kamoche, K. and Bakuwa, R. (2011) Diversity, Organisational Commitment and Organisational Citizenship Behavior: An Organising Framework. Human Resource Management Review, 22, 285-302. http://dx.doi.org/10.1016/j.hrmr.2011.12.003

[15] Shore, M.L. and Martin, J.H. (1989) Job Satisfaction and Organizational Commitment in Relationship to Work Performance and Turnover Intentions. Human Relations, 42, 625-638. http://dx.doi.org/10.1177/001872678904200705

[16] Van Scotter, J.R. (2000) Relationships of Task Performance and Contextual Performance with Turnover, Job Satisfaction and Affective Commitment. Human Resource Management Review, 10, 79-95. http://dx.doi.org/10.1016/S1053-4822(99)00040-6

[17] Cohen, A. (1993) Organisational Commitment and Turnover: A Meta-Analysis. Academy of Management Journal, 36, 1140-1157. http://dx.doi.org/10.2307/256650

[18] Nijhof, J.W., de Jong, M.J. and Beukhof, G. (1998) Employee Commitment in Changing Organisations: An Exploration. Journal of European Industrial Training, 22, 243-248. http://dx.doi.org/10.1108/03090599810224701

[19] Elizur, D. and Koslowsky, M. (2001) Values and Organisational Commitment. International Journal of Manpower, 22, 593-599. http://dx.doi.org/10.1108/01437720110408967

[20] Igbal, A. (2010) An Empirical Assessment of Demographic Factors, Organisational Ranks and Organisational Commitment. International Journal of Business and Management, 5, 16-27.

[21] Amangala, T.A. (2013) The Effects of Demographic Characteristics on Orgnaisational Commitment: A Study of Salespersons in the Soft Drink Industry in Nigeria. European Journal of Business and Management, 5, 109-118.

[22] Becker, H.S. (1960) Notes on the Concepts of Commitment. American Journal of Sociology, 66, 32-42. http://dx.doi.org/10.1086/222820

[23] Oliver, N. (1990) Rewards, Investments, Alternatives and Organizational Commitment; Empirical Evidence and Theoretical Development. Journal of Occupational Psychology, 63, 19-31. http://dx.doi.org/10.1111/j.2044-8325.1990.tb00507.x

[24] Brown, R.B. (1996) Organisational Commitment Clarifying the Concepts and Simplifying the Existing Construct Typology. Journal of Organisationl Behaviour, 49, 230-251.

[25] Scholl, R.W. (1981) Differentiating Organizational Commitment from Expectancy as a Motivation Force. Academy of Management Review, 6, 589-599.

[26] Allen, N.J. and Meyer, J.P. (1991) The Measurement and Antecedents of Affective, Continuance \& Normative Commitment to the Organisation. Journal of Occupatioanl Psychology, 63, 1-18. http://dx.doi.org/10.1111/j.2044-8325.1990.tb00506.x

[27] Angle, H.L. and Perry, J.L. (1981) An Empirical Assessment of Organizational Commitment and Organizational Effectiveness. Administrative Science Quarterly, 27, 1-14. http://dx.doi.org/10.2307/2392596

[28] Allen, N.J. and Meyer, J.P. (1993) Orgnisational Commitment: Evidence of Career Stage Effects? Journal of Business Research, 26, 49-61. http://dx.doi.org/10.1016/0148-2963(93)90042-N

[29] Azeem, S.M. (2010) Personality Hardiness, Job Involvement and Job Burnout among Teachers. International Journal of Vocational and Technical Education, 2, 36-40.

[30] Forkuoh, S.K., Affum-Osei, E., Osei, M.A. and Addo Yaw, V.J. (2014) Employees' Commitment and Growth of Family Businesses. International Journal of Economics, Commerce and Management, 2, 1-14.

[31] McKeown, T. (2003) Commitment from a Contractor Workforce? International Journal of Manpower, 24, 169-186. http://dx.doi.org/10.1108/01437720310475411

[32] Kumasey, S.A., Delle, E. and Ofei, B.S. (2014) Occupational Stress and Organisational Commitment: Does Sex and Managerial Status Matter? International Journal of Business and Social Research (IJBSR), 4, 173-182.

[33] Loscocco, K.A. (1989) The Interplay of Personal and Job Characteristics in Determining Work Commitment. Social 
Science Research, 18, 370-394. http://dx.doi.org/10.1016/0049-089X(89)90013-6

[34] Channar, A.Z., Zareen, A. and Imran, A.U. (2011) Gender Discrimination in Workforce and Its Impact on the Employees. Pakistan Journal of Commerce and Social Sciences, 5, 177-191.

[35] Pourghaz, A., Tamini, K.B. and Karamad, A. (2011) Do Demographic Characteristics Make a Difference to Job Satisfaction, Organizational Commitment and Burnout among Travel Agency Drivers? (A Case Study in Iran). Journal of Basic and Applied Scientific Research, 1, 916-923.

[36] Dodd-McCue, D. and Wright, G.B. (1996) Men, Women \& Attitudinal Commitment: The Effects of Workplace Experiences and Socialization. Human Relations, 49, 1065-1089. http://dx.doi.org/10.1177/001872679604900803

[37] Allen, N.J. and Meyer, J.P. (1990) The Measurement and Antecedents of Affective, Continuance, and Normative Commitment to the Organization. Journal of Occupational Psychology, 63, 1-18. http://dx.doi.org/10.1111/j.2044-8325.1990.tb00506.x

[38] Al-Kahtani, S.N. (2012) An Exploratory Study of Organisational Commitment, Demographic Variables and Job \& Work Related Variables among Employees in Kingdom of Soudi Arabia. Online International Interdisciplinary Research Journal, 3, 1-13.

[39] Steers, R.M. (1977) Antecedents and Outcomes of Organisational Commitment. Administrative Science Quarterly, 22, 46-56. http://dx.doi.org/10.2307/2391745

[40] Igbal, A. (2011) The Impact Assessment of Demographic Factors on Faculty Commitment in the Kingdom of Saudi Arabia Universities. Journal of College Teaching \& Learning, 8, 1-13.

[41] Meyer, J.P. and Allen, N.J. (1997) Commitment in the Workplace: Theory, Research, and Application. Sage, Thousand Oaks.

[42] Angelis, J., Conti, R., Cooper, C. and Gill, C. (2011) Building a High-Commitment Lean Culture. Journal of Manufacturing Technology Management, 22, 569-586. http://dx.doi.org/10.1108/17410381111134446

[43] Punch, K.F. (1998) Introduction to Social Research: Quantitative and Qualitative Approaches. Sage, London.

[44] McMillan, J.H. and Schumacher, S.S. (1997) Research in Education: A Conceptual Introduction. Longman, New York.

[45] Marshall, N.M. (1996) Sampling for Qualitative Research. Family Practice, 13, 522-526. http://dx.doi.org/10.1093/fampra/13.6.522 